DOI: https://doi.org/10.24127/ajpm.v10i4.4290

\title{
PERKULIAHAN HYBRID BERBASIS SELF-REGULATED LEARNING STRATEGIES UNTUK MENINGKATKAN KEMANDIRIAN BELAJAR MAHASISWA
}

\author{
Wiwit Damayanti Lestari $^{{ }^{*}}$, Luthfiyati Nurafifah ${ }^{2}$ \\ ${ }^{1,2}$ Pendidikan Matematika Universitas Wiralodra, Indramayu, Indonesia \\ *Corresponding author. Jalan Ir. H. Djuanda KM3 Singaraja Indramayu, 45213, Indonesia \\ E-mail: $\quad{\frac{\text { wiwitdamayantilestarii@unwir.ac.id }}{\text { luthfiyati.nurafifah@unwir.ac.id }^{2)}}}^{{ }^{*}}$
}

Received 29 September 2021; Received in revised form 17 November 2021; Accepted 25 December 2021

\begin{abstract}
Abstrak
Penerapan Self-regulated learning strategies dalam perkuliahan, baik yang dilaksanakan secara daring maupun luring dapat membantu meningkatkan kemandirian belajar mahasiswa. Tujuan penelitian ini adalah untuk mengetahui bagaimanakah peningkatan kemandirian belajar mahasiswa setelah mengikuti perkuliahan berbasis Self-regulated learning strategies. Penelitian ini adalah penelitian kualitatif deskriptif. Subjek dalam penelitian ini adalah mahasiswa semester 2, 4, dan 6, Prodi Pendidikan Matematika Universitas Wiralodra semester genap tahun ajaran 2020/2021 yang diperoleh dengan teknik purposive sampling. Metode pengumpulan data yang digunakan adalah dokumentasi, kuisioner, dan wawancara. Data kuisioner dinalisis dengan menentukan peningkatan kemandirian belajar melalui penghitungan skor gain ternormalisasi. Hasil penghitungan skor gain ternormalisasi dikonfirmasi dengan hasil wawancara mengikuti langkah analisis data kualitatif, yaitu reduksi data, penyajian data, penarikan kesimpulan, dan verifikasi. Hasil analisis data menunjukkan terjadi peningkatan kemandirian belajar mahasiswa dengan interpretasi rendah setelah mengikuti perkuliahan berbasis Self-regulated learning strategies. Implikasi dari hasil tersebut adalah perkuliahan berbasis Self-regulated learning strategies dapat diterapkan oleh dosen untuk mengembangkan kemandirian belajar mahasiswa sehingga mahasiswa dapat lebih berhasil dalam belajarnya dan meraih prestasi akademik yang lebih baik.
\end{abstract}

Kata kunci: Kemandirian Belajar; Perkuliahan Hybrid; Self-Regulated Learning Strategies

\begin{abstract}
The application of self-regulated learning strategies in lectures, both online and offline, can help increase self-regulated learning. The purpose of this study was to find out how to increase self-regulated learning students after attending lectures based on self-regulated learning strategies. This research is a qualitative-descriptive research. The subjects in this study were $2 n d$, 4th, and 6th semester students of the Mathematics Education Study Program, Wiralodra University, even semester of the 2020/2021 academic year, which were obtained using purposive sampling technique. Data collection methods used are documentation, questionnaires, and interviews. Questionnaire data was analyzed by determining the increase in self-regulated learning strategies through calculating the normalized-gain score. The results of calculating the normalized-gain score were confirmed by interview results following the steps of qualitative data analysis, namely data reduction, data presentation, conclusion drawing, and verification. The results of data analysis showed that there was an increase in self-regulated learning of prospective mathematics teacher with low interpretations after attending lectures based on self-regulated learning strategies. The implication of these results is that lectures based on self-regulated learning strategies can be applied by lecturers to develop student self-regulated learning so that students can be more successful in their studies and achieve better academic achievements.
\end{abstract}

Keywords: Hybrid Lectures; Self-Regulated Learning; Self-Regulated Learning Strategies

This is an open access article under the Creative Commons Attribution 4.0 International License 
DOI: https://doi.org/10.24127/ajpm.v10i4.4290

\section{PENDAHULUAN}

Pandemi covid-19 masih terus belangsung hingga tahun 2021. Kondisi ini berdampak pada proses belajar mengajar di kampus. Status zona tiap kabupaten/kota menjadi pertimbangan bagaimana pelaksanaan proses belajar mengajar. Berdasarkan Surat Edaran Rektor Universitas Wiralodra Nomor 15 Tahun 2020 tentang penyelenggaraan pembelajaran pada semester genap tahun akademik 2020/2021, perkuliahan pada masa pandemi covid-19 pada semester genap tahun akademik 2020/2021 dilaksanakan secara hybrid dengan tetap mengikuti perkembangan pandemi covid-19. Perkuliahan secara hybrid ini dilaksanakan oleh seluruh program studi, tidak terkecuali program studi Pendidikan Matematika Universitas Wiralodra. Perkuliahan hybrid adalah perkuliahan yang dilaksanakan secara bergantian antara daring dan luring, hal ini bertujuan agar mengurangi kerumunan dan mematuhi protokol kesehatan untuk meminimalisir terjadinya penularan covid-19. Pembagian antara perkuliahan yang dilaksanakan secara daring dan luring digilirkan tiap Angkatan. Pada pekan pertama, mahasiswa semester 4 dan 8 melaksanakan perkuliahan secara daring, sedangkan mahasiswa semester 2 dan 6 melaksanakan perkuliahan secara luring, pada pekan berikutnya, perkuliahan dilaksanakan kebalikan dari pekan sebelumnya.

Perkuliahan, baik yang dilaksanakan secara daring maupun luring memerlukan kemandirian belajar mahasiswa yang baik. Kemandirian belajar bukanlah kemampuan mental atau keterampilan kinerja akademis, melainkan proses pengarahan diri sendiri dimana peserta didik mentransformasikan kemampuan mental mereka menjadi keterampilan akademik (Zimmerman, 2002). Kemandirian belajar menjadi salah satu komponen proses belajar-mengajar yang memiliki peran penting dalam meningkatkan kemampuan matematika (Qohar \& Sumarmo, 2013) dan capaian pembelajaran di setiap level Pendidikan (Nugroho, dkk., 2020). Kemandirian belajar meliputi ketidaktergantungan dalam belajar, manajemen diri, kesadaran belajar, dan pemecahan masalah (Ana \& Achdiani, 2015).

Hasil penelitian mengungkapkan bahwa self-regulated learning atau kemandirian belajar berkaitan dengan prestasi akademik siswa dan mahasiswa (Ana \& Achdiani, 2015; Fasikhah \& Fatimah, 2013; Effeney, et al., 2013). Sejalan dengan hal tersebut, hasil penelitian yang lain, mengungkapkan bahwa terdapat hubungan langsung (Lestari, Aisah, \& Luthfiyati, 2020) dan pengaruh positif (Aryani \& Hasyim, 2018; Amalia \& Purwaningsih, 2020) antara kemandirian belajar dan kemampuan pemahaman matematis. Siswa dengan kemandirian belajar yang baik lebih berhasil dalam belajar, sehingga kemandirian belajar yang baik sangat penting dimiliki oleh mahasiswa (Effeney, et al., 2013; Zimmerman, 2002; Wong, et al., 2019; Fasikhah \& Fatimah, 2013). Implementasi pembelajaran blanded learning yang tidak hanya mengandalkan pembelajaran tatap muka namun juga menggunakan internet berpengaruh positif terhadap peningkatan kemandirian belajar (Yanto \& Retnawati, 2018; Octaria, dkk., 2020), hal ini dikarenakan siswa memiliki waktu belajar yang lebih panjang dan dapat mempelajari materi berulang kali (Yanto \& Retnawati, 2018).

Kenyataan di lapangan, berdasarkan hasil penelitian pendahuluan yang dilakukan, diperoleh bahwa self- 
regulated learning atau kemandirian belajar mahasiswa pada umumnya masih rendah, hal ini ditunjukkan dengan kebiasaan mahasiswa hanya mempelajari apa yang ditugaskan kepadanya untuk dipelajari atau hanya menyerap informasi dari dosen saat perkuliahan berlangsung. Mahasiswa belum mengambil inisiatif secara mandiri dalam belajar. Tidak lebih dari 5 mahasiswa di tiap kelas yang mau mempelajari materi perkuliahan secara lebih luas. Hal tersebut ternyata berhubungan langsung dengan hasil belajar. Mahasiswa yang berinisiatif secara mandiri mempelajari materi perkuliahan dengan berbagai cara selain mengikuti perkuliahan, yaitu diskusi dengan teman, bertanya ke kakak tingkat, belajar dari youtube, maupun searching di internet, memiliki kemampuan kognitif diatas rata-rata teman-teman di kelasnya. Hasil tersebut menunjukkan bahwa kemandirian belajar mahasiswa perlu untuk ditingkatkan, sehingga diharapkan mahasiswa dapat sukses dalam perkuliahannya dan dapat juga diterapkan pada hal-hal lain dalam kehidupannya sehari-hari.

Hasil observasi terhadap beberapa pelaksanaan perkuliahan menunjukkan bahwa selama ini perkuliahan yang dilaksanakan baik secara daring atau luring belum maksimal mengembangkan kemandirian belajar mahasiswa. Salah satu cara untuk memacu peningkatan kemandirian belajar adalah dengan menerapkan perkuliahan berbasis self-regulated learning strategies. Self-regulated learning strategies (Zimmerman, 1990), adalah self-evaluation, organization and transformation, goal setting and planning, information seeking, record keeping, self-monitoring, environmental structuring, giving self-consequences, rehearsing and memorizing, seeking social assistance (peers, teacher, or other adults), and reviewing (notes, books, or tests). Hasil penelitian mengenai penerapan strategi pembelajaran self-regulated learning pada pembelajaran menunjukkan hasil yang positif terutama pada peningkatan kemandirian belajar dan kemampuan kognitif (Ana \& Achdiani, 2015; Fasikhah \& Fatimah, 2013; Putra, 2019; Dinata, dkk., 2016). Self-Regulated Learning akan terinternalisasi dalam diri jika dijadikan kebiasaan, dilakukan secara terus-menerus, berulangkali, dan kontinu. Pada penelitian pendahuluan terlihat bahwa masih banyak mahasiswa yang belum melakukan perencanaan, pelaksanaan, pengontrolan dan evaluasi terhadap belajarnya, sehingga pada akhirnya mahasiswa tersebut mengalami underachievement. Kondisi ini harus segera ditanggulangi dengan menerapkan self-regulated learning sebagai strategi pembelajaran pada perkuliahan hybrid untuk meningkatkan kemandirian belajar mahasiswa.

Berdasarkan uraian diatas dan beberapa hasil penelitian yang telah dilakukan sebelumnya, peningkatan kemandirian belajar belum diukur pada penerapan perkuliahan hybrid berbasis self-regulated learning strategies, maka tujuan penelitian ini adalah untuk mengetahui bagaimanakah peningkatan kemandirian belajar mahasiswa setelah mengikuti perkuliahan hybrid berbasis self-regulated learning strategies.

\section{METODE PENELITIAN}

Penelitian ini adalah penelitian kualitatif deskriptif. Langkah-langkah penelitian yang digunakan adalah persiapan, pelaksanaan, dan pelaporan. Penelitian dilakukan selama semester genap tahun ajaran 2020/2021. Subjek dalam penelitian ini adalah mahasiswa 
semester 2, 4, dan 6, Prodi Pendidikan Matematika Universitas Wiralodra semester genap tahun ajaran 2020/2021 yang diperoleh dengan teknik purposive sampling.

Metode pengumpulan data yang digunakan adalah dokumentasi, kuisioner, dan wawancara. Dokumentasi dilakukan terhadap datadata yang diperlukan untuk menjawab rumusan masalah. Kuisioner kemandirian belajar diberikan di awal dan akhir semester, memuat 39 pernyataan dengan skor ideal kemandirian belajar tertinggi adalah 195 dan terendah adalah 39. Kuisioner kemandirian belajar menggunakan skala likert dengan indikator, yaitu a) Inisiatif dan motivasi belajar instrinsik dengan 3 pernyataan; b) Kebiasaan mendiagnosa kebutuhan belajar dengan 5 pernyataan; c) Menetapkan tujuan/target belajar dengan 3 pernyataan; d) Memonitor, mengatur, dan mengkontrol belajar dengan 6 pernyataan; e) Memandang kesulitan sebagai tantangan dengan 6 pernyataan; f) Memanfaatkan dan mencari sumber yang relevan dengan 2 pernyataan; g) Memilih, menerapkan strategi belajar dengan 3 pernyataan; h) Mengevaluasi proses dan hasil belajar dengan 3 pernyataan; i) Self eficacy/ Konsep diri/Kemampuan diri dengan 8 pernyataan. Seorang mahasiswa dengan peningkatan kemandirian belajar tertinggi dan seorang mahasiswa dengan peningkatan kemandirian belajar terendah tiap-tiap angkatan dipilih untuk diwawancara.

Data kuisioner dinalisis dengan menentukan peningkatan kemandirian belajar melalui penghitungan skor gain ternormalisasi (Hake, 1998), terhadap skor kuisioner yang sudah dilakukan perubahan dari data ordinal ke data interval dengan metode successive interval. Berikut adalah rumus dan klasifikasi hasil penghitungan skor gain ternormalisasi:

$$
\begin{aligned}
& g=\frac{S_{\text {pos }}-S_{\text {pre }}}{S M I-S_{\text {pre }}} \ldots(1) \\
& \text { Keterangan: } \\
& S_{\text {pre }} \quad: \text { skor awal } \\
& S_{\text {pos }} \quad: \text { skor akhir } \\
& \text { SMI } \quad \text { : skor ideal tertinggi }
\end{aligned}
$$

Tabel 1. Klasifikasi hasil penghitungan skor gain ternormalisasi

\begin{tabular}{cc}
\hline $\begin{array}{c}\text { Skor Gain } \\
\text { Ternormalisasi }\end{array}$ & Interpretasiasi \\
\hline $\mathrm{g} \geq 0,7$ & Tinggi \\
$0,3 \leq \mathrm{g}<0,7$ & Sedang \\
$\mathrm{g}<0,3$ & Rendah \\
\hline
\end{tabular}

Hasil penghitungan skor gain ternormalisasi dikonfirmasi dengan hasil wawancara mengikuti langkah analysis data kualitatif oleh Miles dan Huberman (1994), yaitu reduksi data, penyajian data, penarikan kesimpulan, dan verifikasi. Verifikasi yang akan dilakukan pada penelitian ini adalah mengkonfirmasi hasil kuisioner dengan wawancara.

Berikut adalah prosedur perkuliahan berbasis self-regulated learning strategies yang digunakan dalam penelitian ini:

1. Tahap Perencanaan: Penataan lingkungan belajar (environmental structuring); Penetapan tujuan dan perencanaan belajar (goal setting and planning);

2. Tahap Pelaksanaan:

Pengorganisasian dan transformasi belajar (organization and transformation); Pencarian informasi (information seeking); Berlatih dan menghafal (rehearsing and memorizing); Membuat catatan (record keeping);

3. Tahap Pengontrolan: Memonitor belajar diri (self-monitoring); Mencari bantuan belajar (seeking social 
assistance: peers, teacher, or other adults); Melakukan review (reviewing: notes, books, or tests);

4. Tahap Evaluasi: Melakukan evaluasi belajar diri (self-evaluation); Memberi konsekuensi diri (giving selfconsequences).

\section{HASIL DAN PEMBAHASAN}

Berikut adalah skor rata-rata kemandirian belajar awal dan akhir pada tiap-tiap indikator dan subjek penelitian, berdasarkan skor yang telah diubah dari data ordinal ke data interval dengan method successive interval. Skor rata-rata kemandirian belajar awal dan akhir mahasiswa semester 2 pada tiap-tiap indikator, disajikan pada Gambar 1.

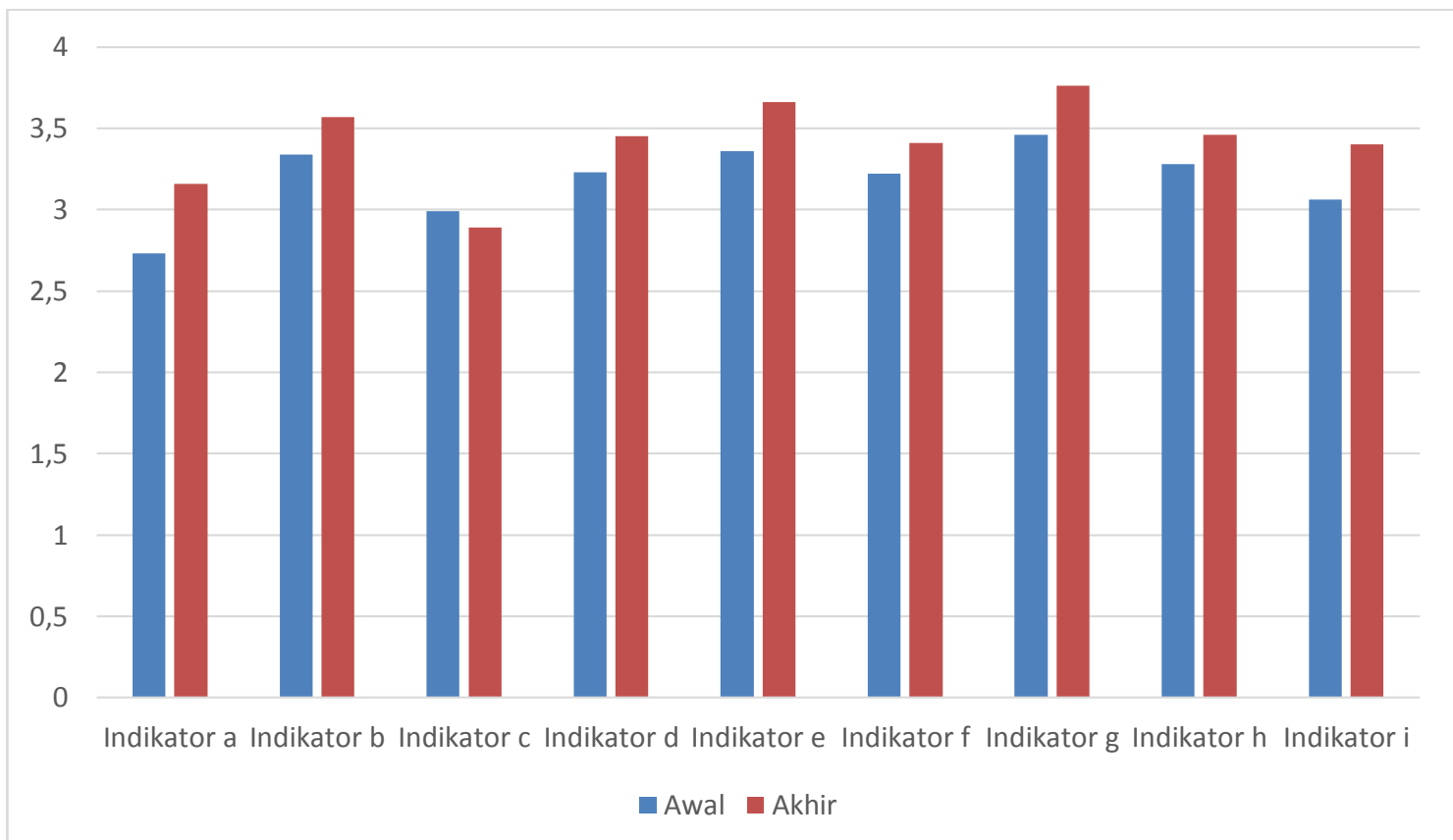

Gambar 1. Skor Rata-Rata Kemandirian Belajar Awal dan Akhir Mahasiswa Semester 2

Berdasarkan data pada Gambar 1, skor rata-rata kemandirian belajar awal mahasiswa semester 2 terendah pada indikator a, yaitu inisiatif dan motivasi belajar instrinsik sebesar 2,73 dan tertinggi pada indikator $\mathrm{g}$, yaitu memilih, menerapkan strategi belajar sebesar 3,46, hasil tersebut menunjukkan bahwa mahasiswa semester 2 belum mempunyai inisiatif dan motivasi belajar instrinsik, namun dapat memilih, menerapkan strategi belajar yang sesuai dengan dirinya. Setelah mengikuti perkuliahan hybrid berbasis self-regulated learning strategies, skor rata-rata kemandirian belajar akhir pada kelompok mahasiswa semester 2 terendah pada indikator c, yaitu menetapkan tujuan/target belajar sebesar 2,89 dan tertinggi pada indikator g, yaitu memilih, menerapkan strategi belajar sebesar 3,76, hasil tersebut menunjukkan bahwa mahasiswa semester 2 belum baik dalam menetapkan tujuan/target belajar, namun sudah baik dalam memilih, menerapkan strategi belajar yang sesuai dengan dirinya. Diantara semua indikator, hanya skor rata-rata pada indikator c yang mengalami penurunan, 
hasil tersebut menunjukkan bahwa diperlukan pembisaan dalam menetapkan tujuan/target belajar pada mahasiswa semester 2. Skor rata-rata

kemandirian belajar awal dan akhir mahasiswa semester 4 pada tiap-tiap indikator, disajikan pada Gambar 2.

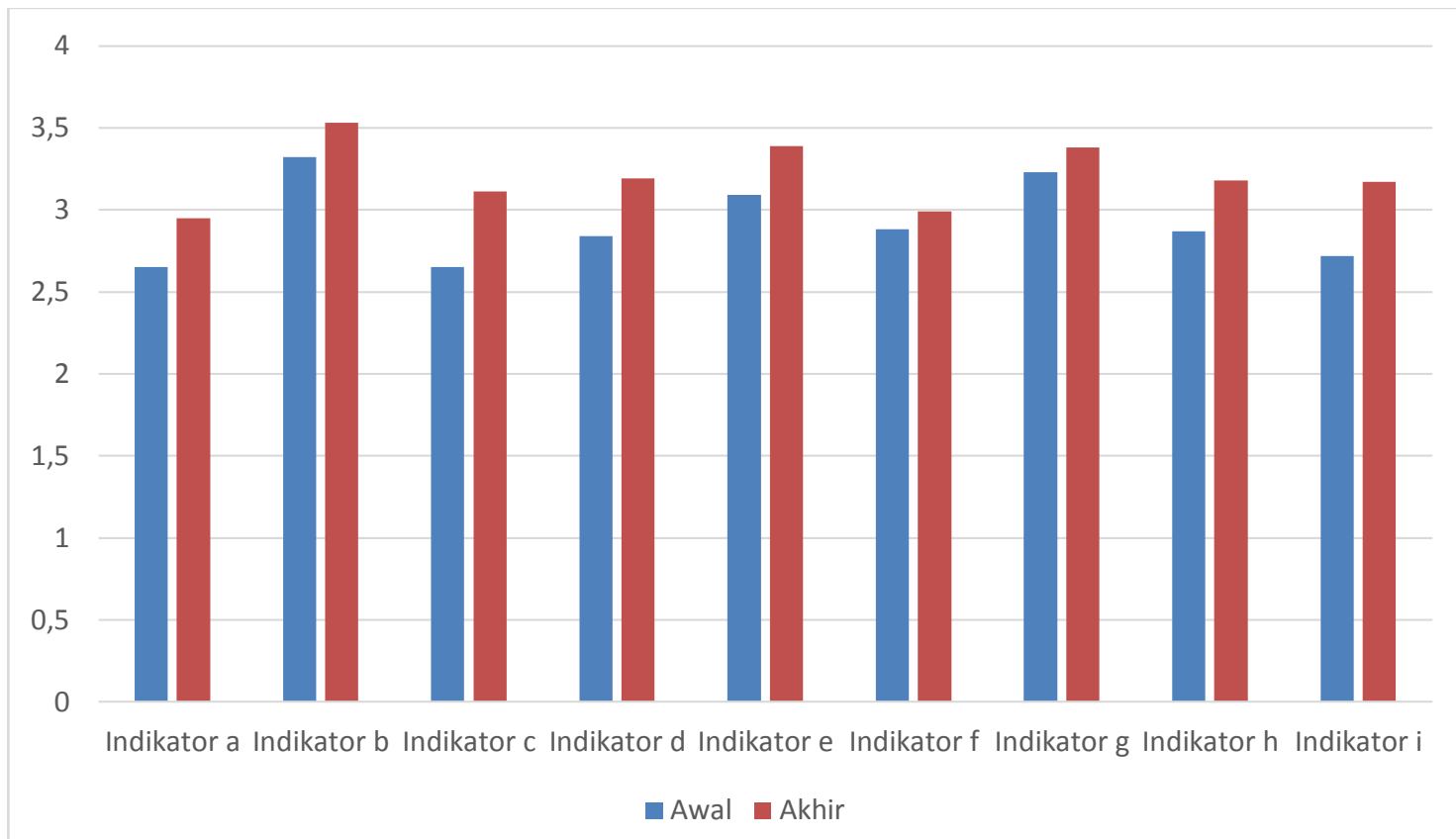

Gambar 2. Skor Rata-Rata Kemandirian Belajar Awal dan Akhir Mahasiswa Semester 4

Berdasarkan data pada Gambar 2, skor rata-rata kemandirian belajar awal mahasiswa semester 4 terendah pada indikator a, yaitu inisiatif dan motivasi belajar instrinsik sebesar 2,65, indikator c, yaitu menetapkan tujuan/target belajar sebesar 2,65 dan tertinggi pada indikator $b$, yaitu kebiasaan mendiagnosa kebutuhan belajar sebesar 3,32 , hal ini berarti bahwa mahasiswa semester 4 belum mempunyai inisiatif dan motivasi belajar instrinsik dan masih belum menetapkan tujuan/target dalam belajar, namun sudah mempunyai kebiasaan mendiagnosa kebutuhan belajar. Skor rata-rata kemandirian belajar akhir mahasiswa semester 4 terendah pada indikator a, yaitu inisiatif dan motivasi belajar instrinsik sebesar 2,95 dan tertinggi pada indikator $b$, yaitu kebiasaan mendiagnosa kebutuhan belajar sebesar 3,53, hal ini berarti bahwa mahasiswa semester 4 masih perlu dilatih lagi dalam inisiatif dan motivasi belajar instrinsik, namun kebiasaan mendiagnosa kebutuhan belajar sudah baik. Skor rata-rata kemandirian belajar awal dan akhir mahasiswa semester 6 pada tiap-tiap indikator, disajikan pada Gambar 3.

Berdasarkan data pada Gambar 3, skor rata-rata kemandirian belajar awal pada kelompok mahasiswa semester 6 terendah pada indikator $\mathrm{f}$, yaitu memanfaatkan dan mencari sumber yang relevan sebesar 2,31 dan tertinggi pada indikator $b$, yaitu kebiasaan mendiagnosa kebutuhan belajar sebesar 3,23, hasil tersebut menunjukkan bahwa mahasiswa semester 6 belum terbiasa dalam memanfaatkan dan mencari sumber yang relevan untuk mendukung 
belajarnya, namun sudah memiliki kebiasaan mendiagnosa kebutuhan belajar. Skor rata-rata kemandirian belajar akhir pada kelompok mahasiswa semester 6 terendah pada indikator $\mathrm{f}$, yaitu memanfaatkan dan mencari sumber yang relevan sebesar 2,73 dan tertinggi pada indikator $b$, yaitu kebiasaan mendiagnosa kebutuhan belajar sebesar 3,38, hasil tersebut menunjukkan bahwa mahasiswa semester 6 perlu dilatih agar dapat memanfaatkan dan mencari sumber yang relevan untuk mendukung belajarnya, namun baik dalam memiliki kebiasaan mendiagnosa kebutuhan belajar. Untuk menggambarkan dengan lebih terperinci mengenai peningkatan dan interpretasinya, berikut adalah data skor kemandirian belajar awal, akhir, gain ternormalisasi, dan interpretasinya yang disajikan pada Tabel 2 .

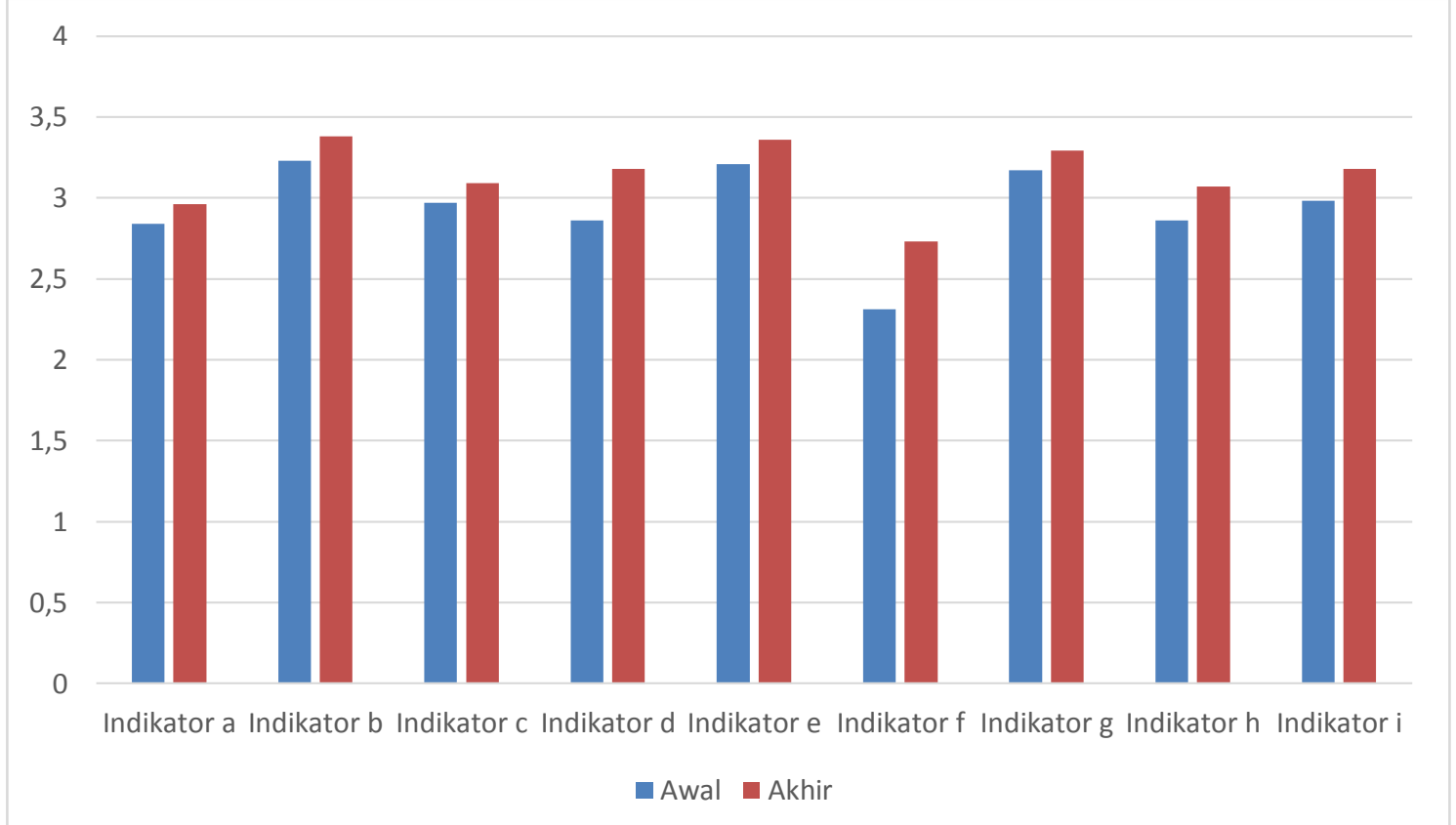

Gambar 3. Skor Rata-Rata Kemandirian Belajar Awal dan Akhir Mahasiswa Semester 6

Tabel 2. Skor Kemandirian Belajar Awal, Akhir, dan Gain Ternormalisasi

\begin{tabular}{ccccc}
\hline Subjek & Skor Awal & Skor Akhir & $\begin{array}{c}\text { Skor Gain } \\
\text { Ternormalisasi }\end{array}$ & Interpretasi \\
\hline S2-1 & 124,93 & 139,36 & 0,21 & rendah \\
S2-2 & 111,08 & 124,14 & 0,16 & rendah \\
S2-3 & 136,99 & 140,57 & 0,06 & rendah \\
S2-4 & 124,93 & 125,75 & 0,01 & rendah \\
S2-5 & 129,8 & 139,23 & 0,14 & rendah \\
S2-6 & 126,14 & 133,35 & 0,1 & rendah \\
S2-7 & 116,28 & 124,95 & 0,11 & rendah \\
S2-8 & 123,82 & 136,99 & 0,18 & rendah \\
S2-9 & 158,46 & 166,7 & 0,23 & rendah \\
S2-10 & 89,43 & 94,83 & 0,05 & rendah \\
S2-11 & 116,43 & 136,99 & 0,26 & rendah \\
S2-12 & 137,39 & 150,42 & 0,23 & rendah \\
\hline
\end{tabular}


DOI: https://doi.org/10.24127/ajpm.v10i4.4290

\begin{tabular}{ccccc}
\hline Subjek & Skor Awal & Skor Akhir & $\begin{array}{c}\text { Skor Gain } \\
\text { Ternormalisasi }\end{array}$ & Interpretasi \\
\hline S2-13 & 123,85 & 133,35 & 0,13 & rendah \\
S4-1 & 93,84 & 101,92 & 0,08 & rendah \\
S4-2 & 94,11 & 115,13 & 0,21 & rendah \\
S4-3 & 131,16 & 148,52 & 0,27 & rendah \\
S4-4 & 127,54 & 135,61 & 0,12 & rendah \\
S4-5 & 115,76 & 147,2 & 0,4 & sedang \\
S4-6 & 133,52 & 137,69 & 0,07 & rendah \\
S4-7 & 97,31 & 109,14 & 0,12 & rendah \\
S4-8 & 123,61 & 129,39 & 0,08 & rendah \\
S4-9 & 97,05 & 122,88 & 0,26 & rendah \\
S4-10 & 119,82 & 123,69 & 0,05 & rendah \\
S4-11 & 135,92 & 138,37 & 0,04 & rendah \\
S4-12 & 117,62 & 123,51 & 0,08 & rendah \\
S4-13 & 94,11 & 108,38 & 0,14 & rendah \\
S6-1 & 144,58 & 148,12 & 0,07 & rendah \\
S6-2 & 109,94 & 123,53 & 0,16 & rendah \\
S6-3 & 101,82 & 119,65 & 0,19 & rendah \\
S6-4 & 104,35 & 145,21 & 0,45 & sedang \\
S6-5 & 136,85 & 141,98 & 0,09 & rendah \\
S6-6 & 94,15 & 99,54 & 0,05 & rendah \\
S6-7 & 130,23 & 136,63 & 0,1 & rendah \\
S6-8 & 121,74 & 128,78 & 0,1 & rendah \\
S6-9 & 106,12 & 113,26 & 0,08 & rendah \\
S6-10 & 101,43 & 108,06 & 0,07 & rendah \\
S6-11 & 118,49 & 127,8 & 0,12 & rendah \\
S6-12 & 130,13 & 133,11 & 0,05 & rendah \\
S6-13 & 91,74 & 91,74 & 0 & rendah \\
S6-14 & 108,25 & 109,74 & 0,02 & rendah \\
S6-15 & 127,2 & 127,2 & 0 & rendah \\
S6-16 & 135,28 & 135,65 & 0,01 & rendah \\
S6-17 & 118,98 & 122,5 & 0,05 & rendah \\
Rata-rata & 118,19 & 127,92 & 0,13 & rendah \\
\hline & & & & \\
\hline
\end{tabular}

Berdasarkan data pada Tabel 2, skor kemandirian belajar awal terendah dan tertinggi pada masing-masing kelompok mahasiswa calon guru matematika semester 2 adalah 89,43 dan 158,46 , semester 4 adalah 93,84 dan 135,92, semester 6 adalah 91,74 dan 144,58, sedangkan skor rata-rata kemandirian belajar awal mahasiswa adalah 118,9. Hal ini menunjukkan mahasiswa calon guru matematika sudah memiliki kemandirian belajar awal yang cukup. Skor kemandirian belajar akhir terendah dan tertinggi pada masing-masing kelompok mahasiswa calon guru matematika semester 2 adalah 94,83 dan 166,70 , semester 4 adalah 101,92 dan 148,52, semester 6 adalah 91,74 dan 148,12, sedangkan skor rata-rata kemandirian belajar akhir mahasiswa adalah 127,92. Skor tersebut menunjukkan bahwa terjadi peningkatan kemandirian belajar mahasiswa calon guru matematika 
DOI: https://doi.org/10.24127/ajpm.v10i4.4290

setelah mengikuti perkuliahan hybrid berbasis self-regulated learning strategies. Hasil ini sesuai dengan penelitian (Ana \& Achdiani, 2015; Putra, 2019; Dinata, dkk., 2016), yang menyatakan bahwa penerapan selfregulated learning dalam pembelajaran dapat meningkatkan kemandirian belajar mahasiswa. Walaupun demikian, data pada tabel 2, menunjukkan bahwa belum ada mahasiswa yang mencapai peningkatan kemandirian belajar dengan interpretasi tinggi setelah mengikuti perkuliahan hybrid berbasis self-regulated learning strategies. Ratarata peningkatan kemandirian belajar mahasiswa adalah 0,13 dengan interpretasi rendah. Berdasarkan hasil wawancara, diperoleh bahwa mahasiswa yang mengalami peningkatan kemandirian belajar sedang memiliki perencanaan, keteraturan dan ketekunan dalam mencapai tujuan yang lebih baik dibandingkan dengan mahasiswa yang mengalami peningkatan kemandirian belajar rendah. Hasil tersebut sesuai dengan pendapat Zimmerman (2002), yang menyatakan bahwa kemandirian belajar bukanlah kemampuan mental atau keterampilan kinerja akademis, melainkan proses pengarahan diri sendiri dimana peserta didik mentransformasikan kemampuan mental mereka menjadi keterampilan akademik. Persentase klasifikasi skor gain ternormalisasi disajikan pada Gambar 4.

\section{Skor Gain Ternormalisasi}

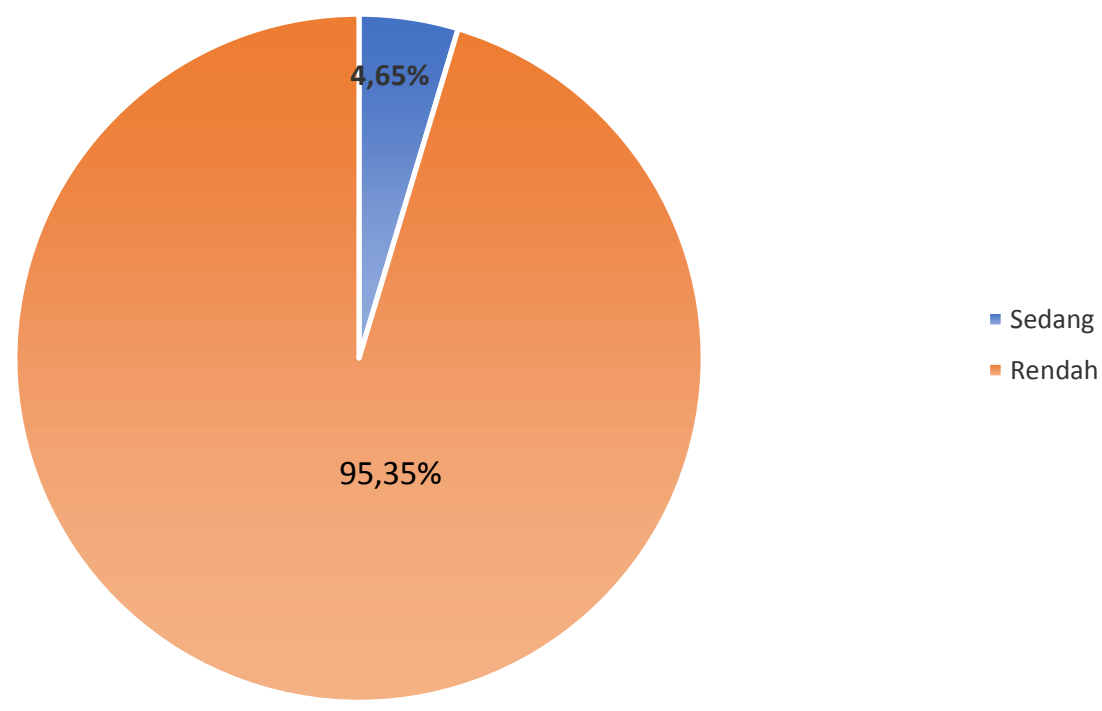

Gambar 4. Persentase Klasifikasi Skor Gain Ternormalisasi

Dari Gambar 4, terlihat bahwa hanya sebanyak 2 mahasiswa mengalami peningkatan sedang atau $4,65 \%$ dari jumlah keseluruhan mahasiswa yaitu 43 orang, sisanya yaitu sebanyak 41 mahasiswa mengalami peningkatan rendah atau $95,35 \%$. Hasil ini disebabkan karena kemandirian belajar perlu dilatih secara kontinu dan dalam jangka waktu yang panjang agar dapat menjadi sebuah kebiasaan yang nantinya akan membentuk karakter. Rata-rata peningkatan sebesar 0,13 dengan interpretasi rendah 
menunjukkan bahwa perkuliahan hybrid berbasis self-regulated learning strategies dapat diterapkan untuk mengembangkan kemandirian belajar mahasiswa. Perkuliahan hybrid berbasis self-regulated learning strategies dapat diterapkan berdampingan dengan penggunaan lembar kerja yang sesuai untuk digunakan oleh dosen dalam meningkatkan kemandirian belajar mahasiswanya, apalagi ditengah tantangan pandemic covid-19 yang dihadapi. Hal ini sejalan dengan hasil penelitian Azka \& Santoso (2015) dan Fitrianna \& Novtiar (2020), yang menyatakan bahwa penggunaan lembar kerja dapat meningkatkan kemandirian belajar.

Dampak dari hasil penelitian yang diperoleh adalah perkuliahan berbasis self-regulated learning strategies dapat diterapkan oleh dosen untuk mengembangkan kemandirian belajar mahasiswa sehingga mahasiswa dapat lebih berhasil dalam belajarnya dan meraih prestasi akademik yang lebih baik.

\section{KESIMPULAN DAN SARAN}

Berdasarkan hasil penelitian dan pembahasan, terjadi peningkatan kemandirian belajar mahasiswa dengan interpretasi rendah setelah mengikuti perkuliahan berbasis self-regulated learning strategies. Implikasi dari hasil tersebut adalah perkuliahan berbasis self-regulated learning strategies dapat diterapkan oleh dosen untuk mengembangkan kemandirian belajar mahasiswa sehingga mahasiswa dapat lebih berhasil dalam belajarnya dan meraih prestasi akademik yang lebih baik. Keterbatasan penelitian ini adalah perkuliahan berbasis self-regulated learning strategies hanya diterapkan pada satu mata kuliah untuk masingmasing kelompok mahasiswa semester
2, 4, dan 6, sehingga hasil peningkatan kemandirian belajar terlihat belum maksimal, untuk penelitian selanjutnya, perkuliahan berbasis self-regulated learning strategies dapat diterapkan pada semua mata kuliah pada masingmasing kelompok mahasiswa dengan jangka waktu yang lebih lama. Perkuliahan hybrid berbasis selfregulated learning strategies juga dapat diimplementasikan dengan menggunakan lembar kerja untuk meningkatkan kemandirian belajar.

\section{UCAPAN TERIMA KASIH}

Penulis mengucapkan terima kasih kepada Universitas Wiralodra yang telah mendanai penelitian ini melalui program hibah internal LPPM skema penelitian dosen utama tahun 2021.

\section{DAFTAR PUSTAKA}

Amalia, S. R \& Purwaningsih, D. (2020). Pengaruh Self Regulated Learning dan Web Course Berbantuan Google Classroom, Whatsapp Group Terhadap Pemahaman Konsep. AKSIOMA, 9(4), 917-925.

DOI: http://dx.doi.org/10.24127/a jpm.v9i4.3009.

Ana \& Achdiani, Y. (2015). Penerapan Self Regulated Learning Berbasis Internet untuk Meningkatkan Kemandirian Belajar Mahasiswa. INVOTEC, XI(1), 15-22.

Aryani, T. D \& Hasyim, M. (2018). Pengaruh Kecemasan Matematis, Problem Stress Matematika dan Self-Regulated Learning Terhadap Hasil Belajar Matematika Siswa. AKSIOMA, 7(2), 243-252. DOI: http://dx.doi.org/10.24127/a jpm.v7i2.1422. 
Azka, R \& Santoso, R. H. (2015). Pengembangan Perangkat Pembelajaran Kalkulus untuk Mencapai Ketuntasan dan Kemandirian Belajar Siswa. Jurnal Riset Pendidikan Matematika, 2(1), 78 - 91. DOI: http://dx.doi.org/10.21831/i rpm.v2i1.7152.

Yanto, B \& Retnawati, H. (2018). Dapatkah Model Blended Learning Mempengaruhi Kemandirian Belajar Matematika Siswa?. AKSIOMA, 7(3), 324333.

DOI: http://dx.doi.org/10.24127/a jpm.v7i3.1559.

Dinata, P. A. C., Rahzianta, \& Zainuddin, M. (2016). Self Regulated Learning Sebagai Strategi Membangun Kemandirian Peserta Didik Dalam Menjawab Tantangan Abad 21. Prosiding Seminar Nasional Pendidikan Sains (SNPS) 2016: Peningkatan Kualitas Pembelajaran Sains dan Kompetensi Guru Melalui Penelitian \& Pengembangan dalam Menghadapi Tantangan Abad-21, 139-146.

Effeney, G., Carroll, A., \& Bahr, N. (2013). Self-Regulated Learning: Key Strategies and Their Sources in a Sample of Adolescent Males. Australian Journal of Educational \& Developmental Psychology, 13, 58-74.

Fasikhah, S. S \& Fatimah, S. (2013). Self-Regulated Learning (SRL) Dalam Meningkatkan Prestasi Akademik pada Mahasiswa. Jurnal Ilmiah Psikologi Terapan, 1(1), 145-155.

Fitrianna, A. Y \& Novtiar, C. (2020). Worksheet Berbantuan Maple untuk Meningkatkan
Algebraic Reasoning dan SelfRegulated Learning. AKSIOMA, 9(2), 378-386. DOI: http://dx.doi.org/10.24127/a jpm.v9i2.2772.

Hake, R. R. (1998). InteractiveEngagement Versus Traditional Methods: A Six ThousandStudent Survey of Mechanics Test Data for Introductory Physics Courses. American Journal Physics, 66(1), 64-74.

Hidayat, W \& Sumarmo, U. (2013). Kemampuan Komunikasi dan Berpikir Logis Matematik Serta Kemandirian Belajar: Eksperimen terhadap Siswa SMA Menggunakan Pembelajaran Berbasis Masalah dan Strategi Think-Talk-Write. Delta-Pi: Jurnal Matematika dan Pendidikan Matematika, 2(1), 114.

Lestari, W. D., Aisah, L. S., \& Luthfiyati, N. (2020). What is The Relationship Between SelfRegulated Learning and Students' Mathematical Understanding in Online Lectures During The Covid-19 Pandemic?. J. Phys. Conf. Ser. 1657012065.

Miles, M. B., \& Huberman, M. (1994). Qualitative Data Analysis: An Expanded Sourcebook 2nd ed. California: SAGE Publications Inc.

Nugroho, A. A., Juniati, D., \& Siswono, T. Y. E. (2020). Self-Regulated Learning Of Prospective Mathematics Teachers With Different Learning Styles. Beta: Jurnal Tadris Matematika, 13(1), 81-103.

DOI: https://doi.org/10.20414/betajtm. v13i1.344.

Octaria, D., Fitriasari, P., \& Sari, N. (2020). Blended Learning dengan 
DOI: https://doi.org/10.24127/ajpm.v10i4.4290

Macromedia Flash untuk Melatih

Kemandirian Belajar Mahasiswa.

Jurnal Elemen, 6(1), 25-38.

DOI: https://doi.org/10.29408/jel. v6i1.1596.

Putra, D. P. W. (2019). Pembelajaran Matematika dengan Pendekatan Self-Regulated Learning untuk Membangun Kemandirian Belajar Siswa. SQUARE: Journal of Mathematics and Mathematics Education, 1(1), 49-54. DOI : https://doi.org/10.21580/square. 2019.1.1.4121.

Qohar, A \& Sumarmo, U. (2013). Improving Mathematical Communication Ability and Self Regulation Learning Of Yunior High Students by Using Reciprocal Teaching. IndoMS. J.M.E, 4(1), 59-74. DOI: https://doi.org/10.22342/jm e.4.1.562.59-74.

Wong, J., Baars, M., Davis, D., Zee, T. V. D., Houben, G., \& Paas, F. (2019). Supporting SelfRegulated Learning in Online Learning Environments and MOOCs: A Systematic Review. International Journal of HumanComputer Interaction, 35(4-5), 356-373.

DOI: https://doi.org/10.1080/104 47318.2018.1543084.

Zimmerman, B. J. (1990). SelfRegulated Learning and Academic Achievement: An Overview. Educational Psychologist, 25(1), 3-17.

Zimmerman, B. J. (2002). Becoming a Self-Regulated Learner: An Overview. Theory into Practice, 41(2), 64-70. 